\title{
Oral squamous cell carcinomas developing from oral lichen planus: Do they differ in recurrence and metastatic potential?
}

Research article

Keywords:

Posted Date: May 28th, 2021

DOI: https://doi.org/10.21203/rs.3.rs-530974/v2

License: (c) (i) This work is licensed under a Creative Commons Attribution 4.0 International License.

Read Full License 


\section{Abstract}

The authors have requested that this preprint be withdrawn due to erroneous posting.

\section{Full Text}

The authors have withdrawn this preprint from Research Square. 